\title{
SUPERALLOYS FOR ADVANCED ENERGY APPLICATIONS: INCONEL ALLOY 740H - A CASE STUDY ON INTERNATIONAL GOVERNMENT-INDUSTRY-UNIVERSITY COLLABORATION
}

\author{
John deBarbadillo ${ }^{1}$, Brian Baker ${ }^{1}$ and Xishan $\mathrm{Xie}^{2}$ \\ ${ }^{1}$ Special Metals Corporation, Huntington, WV, USA \\ ${ }^{2}$ University of Science and Technology Beijing, Beijing, China
}

Keywords: Advanced Energy Systems, Alloy 740H, Tube, Pipe, Forging, Welding, Creep Rupture

\begin{abstract}
A number of national and international collaborative projects have been underway for almost twenty years, with the goal of increasing the efficiency of coal-fired power plants. Nickel-base superalloys are enabling materials to achieve the design goals for operating temperature, pressure and service life of Advanced Ultra-supercritical (AUSC) concept plants. Over this time frame, new alloys have been developed, characterized and qualified, fullsize components have been manufactured and engineering designs developed for demonstration plants. INCONEL ${ }^{\circledR}$ alloy $740 \mathrm{H} \AA$, a $\gamma^{\prime}$-strengthened superalloy formulated specifically for tube and pipe in AUSC power plants, is a key alloy for plants now being designed or under construction. This paper describes the development and qualification of this alloy with emphasis on the collaborative nature of the project.
\end{abstract}

(B) INCONEL, NIMONIC and $740 \mathrm{H}$ are registered trademarks of Special Metals Corporation.

\section{Introduction}

Nickel-base superalloys were enabling materials for the aircraft turbine engine. The history of their co-evolution, beginning with the historic Whittle engine in 1940, has been chronicled by Sims [1,2] and Betteridge [3]. By the late 1940s superalloys were being modified for service in marine and small power turbines [4]. Both cast and wrought alloys with improved hot corrosion resistance were introduced to contend with the degrading effect of dirty fuels. In the early 1990's General Electric Power pioneered a new family of large-frame gas turbines that used alloy 706 wheels and spacers [5]. This development overcame numerous metallurgical and manufacturing problems posed by a ten-fold increase in part size. Today more than a thousand of these turbines are in use throughout the world.

Historically, steam turbines powered by coal-fired boilers have operated in a temperature regime where ferritic or austenitic steels could be used. Over the years, the operating temperatures and pressures of these plants have been steadily increasing. Figure 1 shows the progression of temperature, pressure and nominal efficiency of four generations of fossil-fired power plants. The designations are somewhat arbitrary as the evolution has been more of a continuum as designs evolved. Ultra-supercritical (USC) is the current state of the art as represented in the U.S. by Southwest Electric Power Company (SWEPCO) John. W. Turk plant in Fulton, Arkansas. Advanced Ultra-supercritical (AUSC) represents the next generation plant where the steam temperature will be at least $700^{\circ} \mathrm{C}$ and nickel-base alloys will be required.

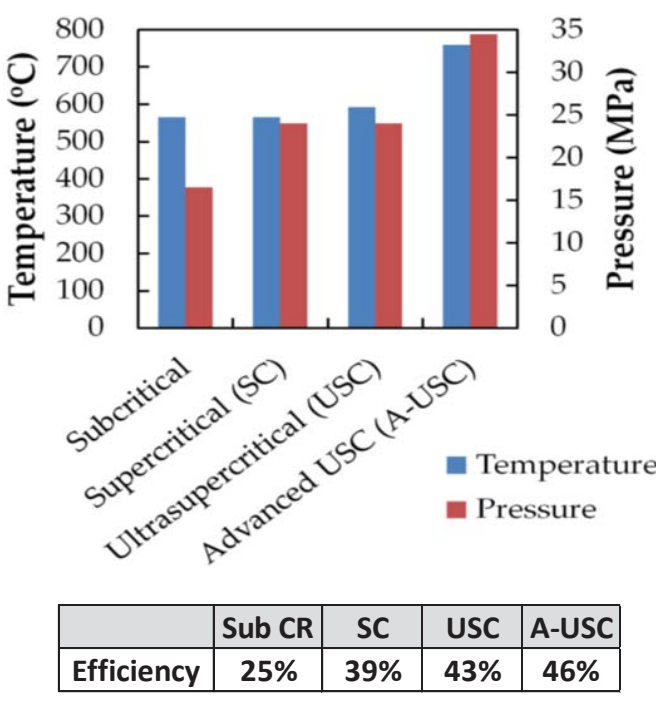

Figure 1. Progression in operating temperature for US coal fired power boilers [6].

The motivation for this increase is the greater efficiency and fuel economy of the Rankine Cycle system at higher temperatures and pressures. When the cost of $\mathrm{CO}_{2}$ emissions by carbon capture and sequestration or carbon tax is considered, the efficiency reward is significantly increased [7]. While operating conditions have increased, the basic design of coal-fired boilers has remained essentially the same. This has an advantage of minimizing the cost of qualifying improved systems and enables upgrade of performance through retrofitting older plants with new technology. There is a limit to this approach, but the premise of AUSC is that at least one more technology cycle is possible.

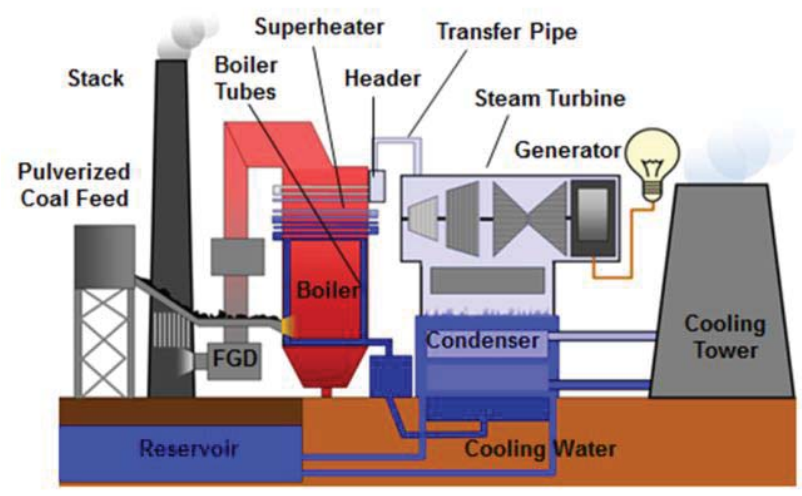

Figure 2. Generalized design of a coal fired power plant 
Through the years, the capability of ferritic $9-12 \%$ chromium steels has progressively increased. Much of this development work was done in Europe under the collaborative framework of the COST program and in Japan through the leadership of National Institute of Materials Science (NIMS). But an operating temperature of about $620^{\circ} \mathrm{C}$ appears to be the practical limit for ferritic steels $\left(650{ }^{\circ} \mathrm{C}\right.$ may be possible). Systems designers have projected that the current physical design of a pulverized coal fired power boiler can work with much greater efficiency at still higher temperatures and pressures provided suitable alloys will be available.

In 1998 forty companies, including Special Metals, joined the Thermie AD700 project to develop materials for service in a boiler operating with a steam temperature of $700^{\circ} \mathrm{C}$ [8]. This concept later came to be known world-wide as the "Advanced Ultra-supercritical Steam Boiler" (AUSC). Both solid-solution and age-hardened alloys were evaluated in the Thermie project for their capability for use in critical components such as boiler tubes, steam transfer pipes, valve bodies, turbine rotors, buckets and casings. Promising alloys from this program were evaluated through a series of projects culminating in the installation of a component test facility at the E.ON SE Schölven power plant in Gelsenkirchen, Germany in 2004. This project was designated COMTES700. One of the nickel-base alloys to emerge from these projects was alloy 740 (UNS N07740) that was derived from the aerospace sheet alloy NIMONIC 263. This alloy was formulated to meet the strength and fire-side corrosion targets of the early European program as tubing for the superheater section of the boiler. Alloy 740 was the first age-hardened nickel-base alloy to be considered for boiler use [9]. Several commercial-scale VIM/ESR heats were melted at Special Metals Wiggin in Hereford UK, and tubing was supplied for exposure in COMTES700. Many additional projects under the European collaborative $R \& D$ umbrella have since been conducted to test materials for specific components, and a demonstration facility is now on the drawing board.

The US AUSC program got underway in 2001. It is a public/private consortium that is financially supported by the US DOE, Office of Fossil Energy and the Ohio Coal Development Office. The organizing membership of the boiler and turbine projects included Alstom, Babcock \& Wilcox, Foster Wheeler, Riley Power, Siemens and GE Energy. The National Energy Technology Lab (NETL) and Oak Ridge National Lab (ORNL) were key participants. The Electric Power Research Institute (EPRI) provided technical leadership. The US consortium operating condition goals were much more ambitious than those of the other national programs, targeting $760{ }^{\circ} \mathrm{C}$ and $35 \mathrm{MPa}$ steam temperature and pressure to gain maximum efficiency return for the costly investment in new materials [10,11]. The US consortium considered many materials in its initial screening including alloy 740. One of the consequences of the more stringent operating conditions was that age-hardened alloys would be needed in other components of the plant such as steam transfer pipe, turbine rotors and casings and valve parts that involved much thicker cross-section than boiler tube. Alloy 740 was found to have two shortcomings: 1) $\gamma^{\prime}$ was unstable at $760{ }^{\circ} \mathrm{C}$ and was replaced by acicular $\eta$ that had a detrimental effect on impact toughness [12], and 2) liquation cracking occurred at the fusion line in thick section welds [13]. Fortunately a detailed microstructural analysis of 740 and various modifications was already underway in a project at the University of Science and
Technology Beijing that was sponsored by Special Metals. This work pointed the way to a modified composition (later designated alloy $740 \mathrm{H}$ ) that met the US AUSC Consortium requirements for steam transfer pipe as well as boiler tube [14]. The consortium then embarked on an extensive testing program that culminated in the creation of a detailed test package that served as the basis for ASME code case 2702 [15]. Alloy $740 \mathrm{H}$ is the first age-hardened alloy to be approved for use in welded pressure service in the creep limited temperature region. Many countries follow ASME requirements for boiler design, so this was a technological milestone.

The US Consortium has continued to develop AUSC technology. Boiler tube exposure tests at several operating power plants were conducted. A new grant from DOE is funding an engineering study for a fractional-scale power plant that would enable continuous operation testing of both boiler and turbine. This plant will be the culmination of a great deal of work both by the US consortium and material suppliers as well as input from national programs in Europe, Japan, China, Korea and India. Alloy $740 \mathrm{H}$ as a first of a kind material will play a key role in this plant. The construction and operating experience will be important for further improvement of alloy $740 \mathrm{H}$ as well as other age-hardened alloys that will emerge in the future. This paper addresses key issues in the development and qualification of the alloy with emphasis on the collaborative nature of the project.

\section{Results and Discussion}

\section{Does the Alloy Meet Design Property Targets?}

Alloy 740 was developed in the Thermie project [8] for boiler tube with two nominal material property targets in mind: 100,000 $\mathrm{h}$ rupture strength of $100 \mathrm{MPa}$ at $700{ }^{\circ} \mathrm{C}$ and a corrosion/oxidation metal loss of less than $2 \mathrm{~mm}$ in $200,000 \mathrm{~h}$. The initial alloy design assumptions were a nominal $15 \% \gamma^{\prime}$ for strength and an increased chromium and decreased molybdenum content for resistance to coal ash corrosion. The nominal composition of 263, 740 and $740 \mathrm{H}$ are listed in Table 1. A solution heat-treatment of $1100^{\circ} \mathrm{C}$ min followed by aging for $4 \mathrm{~h}$ minimum at $760{ }^{\circ} \mathrm{C}$ to $816^{\circ} \mathrm{C}$ was specified.

Table 1. Nominal compositions in weight percent of alloys 263, 740 and $740 \mathrm{H}$. Balance is nickel and residual elements.

\begin{tabular}{|c|c|c|c|c|c|c|c|}
\hline Alloy & Cr & Co & Mo & Al & $\mathrm{Ti}$ & $\mathrm{Nb}$ & $\mathrm{Si}$ \\
\hline 263 & 20 & 20 & 6 & 0.4 & 2.2 & $\mathrm{R}$ & 0.15 \\
\hline 740 & 24.5 & 20 & 0.5 & 0.9 & 1.8 & 2 & 0.5 \\
\hline $740 \mathrm{H}$ & 24.5 & 20 & 0.5 & 1.35 & 1.35 & 1.5 & 0.15 \\
\hline
\end{tabular}

The US Consortium goals were similar but more difficult to achieve due to the planned higher operating temperature. ORNL was given the task of developing comprehensive creep-rupture data. Material was supplied as tube from 740 heats melted at Special Metals Wiggin and bar and plate from $740 \mathrm{H}$ heats melted in Special Metals Huntington. This creep rupture testing program is ongoing with tests now hanging that will exceed 100,000 h. The temperature range covered is $600{ }^{\circ} \mathrm{C}$ to $875{ }^{\circ} \mathrm{C}$. The results obtained to date, shown in Figure 3, contain both 740 and $740 \mathrm{H}$ data [16]. The projected $100,000 \mathrm{~h}$ rupture strength is $210 \mathrm{MPa}$ at $700{ }^{\circ} \mathrm{C}$ and $120 \mathrm{MPa}$ at $750{ }^{\circ} \mathrm{C}$. Tortorelli et al concluded that the two alloy variants have similar creep strength [17]. This data is the basis for the American Society of Mechanical Engineers 
(ASME) allowable stress values for Code Case 2702. These values are shown in Figure 4 for $740 / 740 \mathrm{H}$ and several other high temperature alloys. It was concluded that $740 \mathrm{H}$ does meet the design creep-rupture strength goals.

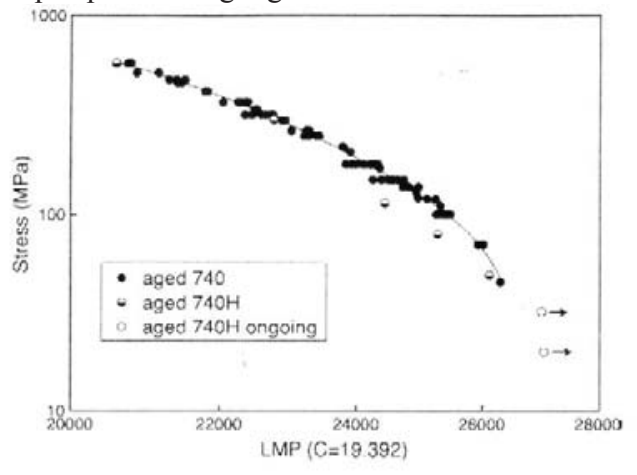

Figure 3. Optimized Larson-Miller Parameter plot $(\mathrm{T} .\{\log (\mathrm{t})+\mathrm{C}\}$, $\mathrm{C}=19.392$ ) for alloy $740 / 740 \mathrm{H}$ creep-rupture test data segmented by heat. Open symbols are on-going tests [17].

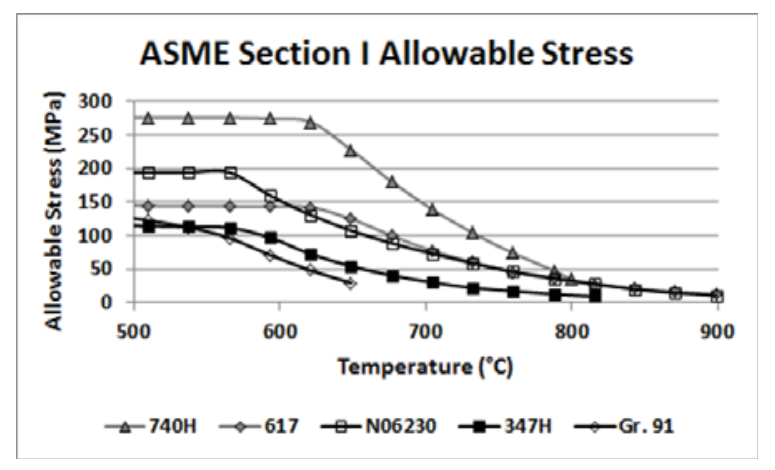

Figure 4. ASME Section I allowable stress values for code case 2702 compared to other high temperature alloys [15].

Obviously other mechanical properties are also important. Product acceptance for ASME Code Case 2702 and ASTM B-983 (pipe and tube) specs is based on yield strength and ductility rather than creep strength. Impact toughness of the base metal is on the order of $100 \mathrm{~J} / \mathrm{cm}^{2}$ when the material is in its optimal aged condition, but declines over time when exposed in the $700{ }^{\circ} \mathrm{C}$ to $800{ }^{\circ} \mathrm{C}$ temperature range. This effect is discussed in more detail in the next section. Fatigue and creep fatigue properties are of increasing importance because fossil-fired power plants may be operated in a peaking mode in the future to complement the diurnal cycles of some renewable energy sources. Limited strain controlled fatigue tests conducted to date on $740 \mathrm{H}$ showed excellent properties [18]. More comprehensive testing is under way.

Resistance to environmental attack is more difficult to assess because multiple environments exist in different areas of the boiler. Many assessments of the oxidation resistance of $740 \mathrm{H}$ under conditions representative of the steam side of the boiler tube have been published [19]. The principal concern is exfoliation of oxide scale that could potentially clog boiler tubes. Maitra summarized this work and concluded that many nickel alloys including $740 \mathrm{H}$ that have more than $20 \% \mathrm{Cr}$ have low corrosion rates in air and steam with parabolic weight gain and adherent oxide scales. He concluded that these alloys are suitable for use on the steam-side of AUSC plants [20].
The fire-side corrosion attack is dependent on boiler firing conditions, fuel impurities, de-slagging practices, operating temperature, as well as location within the boiler. Furthermore laboratory simulations may provide misleading or inconsistent results. Boiler corrosion occurs by a fluxing reaction of alkali metal tri-sulfates deposited on the surface of the tubes. The conditions for maximum pitting attack are thought to be most severe in the planned AUSC operating temperature range of 700 ${ }^{\circ} \mathrm{C}$ to $800{ }^{\circ} \mathrm{C}$ where deposits are in the liquid state [21]. Alloying elements such as molybdenum and tungsten are known to accelerate the rate of attack by breaking down the protective chromia scale. Alloy $740 \mathrm{H}$ was designed to minimize refractory element content for this reason. This effect is shown in a laboratory simulation by Baker et al where both welded and unwelded samples of alloys 617 and $740 \mathrm{H}$ were exposed for up to $1000 \mathrm{~h}$ in a simulated high sulfur coal ash [22]. These results are shown in Figure 5. Note that there was no selective attack at the weld despite its chemical inhomogeneity. Independent laboratory studies of coal ash corrosion of alloy $740 \mathrm{H}$ have shown similar results. This work was summarized by Smith [23]. One problem with these studies is that they do not capture the variability resulting from coal composition. The US DOE sponsored work at Babcock \& Wilcox to provide a broader perspective [24]. In this work eight common US coals were burned to create synthetic ash deposits. Selected alloys were then exposed to this ash in a controlled combustion atmosphere in a pilot scale boiler for 1000 $\mathrm{h}$ at $704{ }^{\circ} \mathrm{C}$. Alloy 740 (the only nickel-base alloy tested) showed relatively low corrosion rates except in contact with high-chlorine Illinois \#6 Gallatia coal where extensive pitting was observed. This highlights the need to thoroughly evaluate the performance of super-heater alloys in the expected fuel environment.

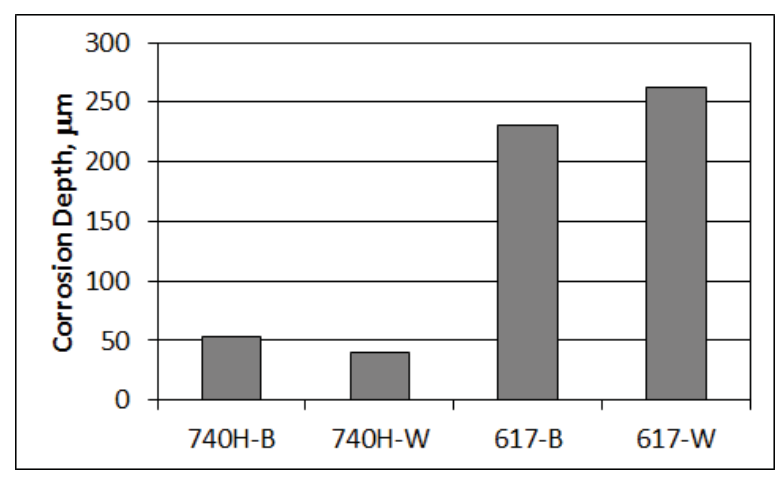

Figure 5. Maximum pit depth for base metal and weld metal samples for alloys 617 and $740 \mathrm{H}$ in a simulated Chinese coal ash $\left(750^{\circ} \mathrm{C}, 1000 \mathrm{~h}\right)$ [22].

Alloy $740 \mathrm{H}$ has also been exposed to in-plant test loops in Europe and the US where it has shown excellent performance. The most recent exposure for $16,000 \mathrm{~h}$ in a steam cooled loop at Southern Co. James M. Barry plant in Bucks, Alabama was completed in 2014. Initial results indicate 740 performed well [25]. Based on the results of these tests, it is concluded that alloy $740 \mathrm{H}$ does meet the coal ash corrosion requirements for use uncoated as boiler tube. On the other hand, alloy $740 \mathrm{H}$ is not immune to attack by ash from high $\mathrm{S}$ and $\mathrm{Cl}$ coals under AUSC conditions, so careful monitoring will be needed until broader operating experience is gained. 


\section{Is the Microstructure Stable for the Design Life of the Power Plant?}

As noted previously, early assessments of microstructure of 740 showed that $\gamma^{\prime}$ was unstable and that acicular $\eta$ formed during exposure at temperatures above $725^{\circ} \mathrm{C}$. Globular G-phase was also observed [12]. Typical microstructures for as heat-treated and long-time aged alloy 740 are shown in Figure $6 \mathrm{a}$ and $6 \mathrm{~b}$. Shingledecker concluded that $\eta$ had no effect on creep-rupture life and ductility [26]; however, Special Metals data showed that $\eta$ had an adverse effect on impact toughness. It was observed that the room temperature Charpy impact toughness dropped from about $100 \mathrm{~J} / \mathrm{cm}^{2}$ as-aged, to less than $10 \mathrm{~J} / \mathrm{cm}^{2}$ after exposure at $750{ }^{\circ} \mathrm{C}$ for $1000 \mathrm{~h}$. Based on this information, variations of $\mathrm{Al}, \mathrm{Ti}$ $\mathrm{Nb}$ and $\mathrm{Si}$ were explored using phase equilibrium modeling and experimental heats. The resulting optimized stable composition became $740 \mathrm{H}$.
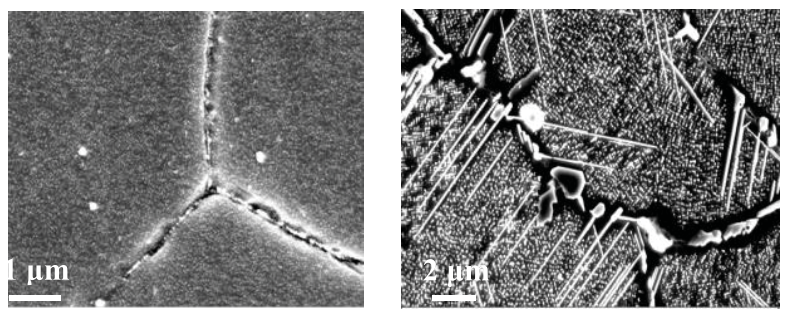

Figure 6. a) Microstructure of 740 after standard aging treatment, b) Microstructure after aging for $2000 \mathrm{~h}$ at $760{ }^{\circ} \mathrm{C}$ [12].

At the time the $740 \mathrm{H}$ modification was introduced, it was realized that many of the AUSC candidate superalloys were also unstable. Consequently an effort was made to verify $740 \mathrm{H}$ stability without actually testing for $100,000 \mathrm{~h}$. This work was done on several levels and is to some degree on-going. The results of phase diagram modeling for the nominal $740 \mathrm{H}$ composition using JMatPro software using the nickel alloy database is shown in Figure 7. Note that the region of $\eta$ stability has been restricted to a narrow range around $1000{ }^{\circ} \mathrm{C}$ which is well above the operating range for AUSC. Of course, commercial alloys have a range of composition, but model sensitivity studies show that the alloy will be generally free of $\eta$.

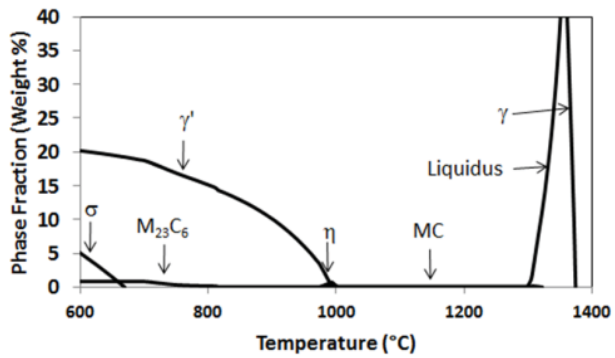

Figure 7. Simulation of the weight fraction of equilibrium phases for the nominal $740 \mathrm{H}$ composition (JMatPro).

To verify the microstructure stability, specimens of $740 \mathrm{H}$ given the standard heat treatment were exposed stress-free at $700{ }^{\circ} \mathrm{C}$, $750^{\circ} \mathrm{C}$ and $800^{\circ} \mathrm{C}$ for times up to $10,000 \mathrm{~h}$. The microstructures in the as-aged condition and after exposure for $5000 \mathrm{~h}$ at $750^{\circ} \mathrm{C}$ are shown in Figures $8 \mathrm{a}$ and $8 \mathrm{~b}$. The only changes noted are an increase in the volume of $\mathrm{M}_{23} \mathrm{C}_{6}$ carbide at the grain boundaries and coarsening of the $\gamma^{\prime}$ particles. The cuboidal nature of the $\gamma^{\prime}$ is more evident after long time exposure.
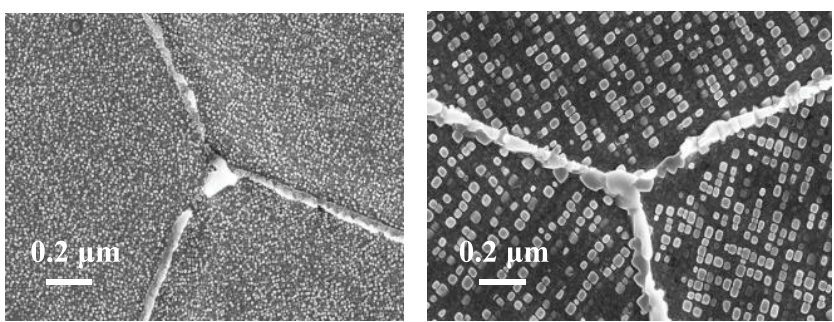

Figure 8. a) Microstructure of alloy $740 \mathrm{H}$ in as aged condition, b) microstructure after exposure for $5000 \mathrm{~h}$ at $750{ }^{\circ} \mathrm{C}$ [27].

Chi and co-workers also measured the $\gamma^{\prime}$ particle diameter for the various aging times and temperatures [27]. These results are shown in Figure 9. Virtually no change in $\gamma^{\prime}$ size occurs at $700{ }^{\circ} \mathrm{C}$, while growth at $800{ }^{\circ} \mathrm{C}$ is rather rapid. The volume fraction of $\gamma^{\prime}$ was not measured, but it should be approximately constant at $15 \%$ at $800{ }^{\circ} \mathrm{C}$. The equilibrium $\gamma^{\prime}$ content is about $18 \%$ at $700{ }^{\circ} \mathrm{C}$

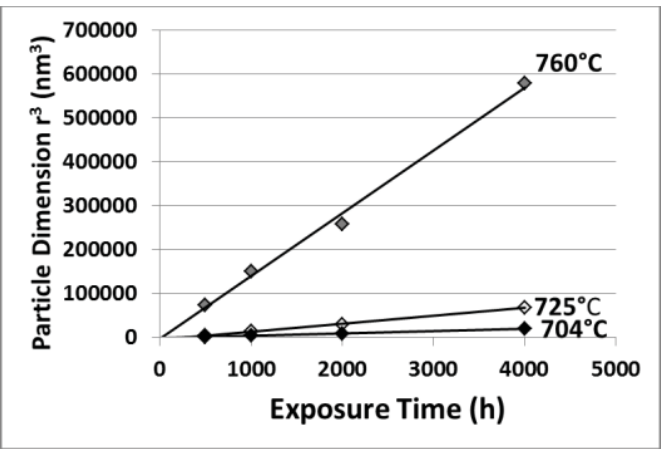

Figure 9. Measured $\gamma^{\prime}$ size for long time stress-free exposure.

Mechanical properties were also determined for the material discussed above. Charpy V-notch impact toughness testing was conducted on specimens aged for up to $10,000 \mathrm{~h}$ at the three temperatures. Impact toughness dropped progressively during the first $1000 \mathrm{~h}$ of exposure, but then leveled off to a range of 20-30 $\mathrm{J} / \mathrm{cm}^{2}$. This level of toughness is considered acceptable for the application [28]. The initial reduction in toughness is attributed to additional precipitation of $\mathrm{M}_{23} \mathrm{C}_{6}$ carbide at the grain boundaries and a trend to inter-granular fracture mode [27].

\section{Can the Alloy be made in Component Sizes and Configurations Required?}

Alloy 740 was intended initially for use as boiler tubing, for which conventional $500 \mathrm{~mm}$ diameter VIM/ESR ingots were suitable as starting stock. Tube was made in 2005 for the European COMTES700 project at the Special Metals plant in Hereford UK. Billets cut from forged rod were extruded to tube shell and then reduced in diameter and wall thickness to final size using successive cold-work and process anneal cycles. The tube processing for alloy $740 / 740 \mathrm{H}$ is similar to that of other hard alloys such as 625 . Subsequently, a range of tube sizes shown in Figure 10 have been produced in 740 and $740 \mathrm{H}$. The smallest diameter tubes were produced for a supercritical $\mathrm{CO}_{2}\left(\mathrm{sCO}_{2}\right)$ heat exchanger under construction in the US. 


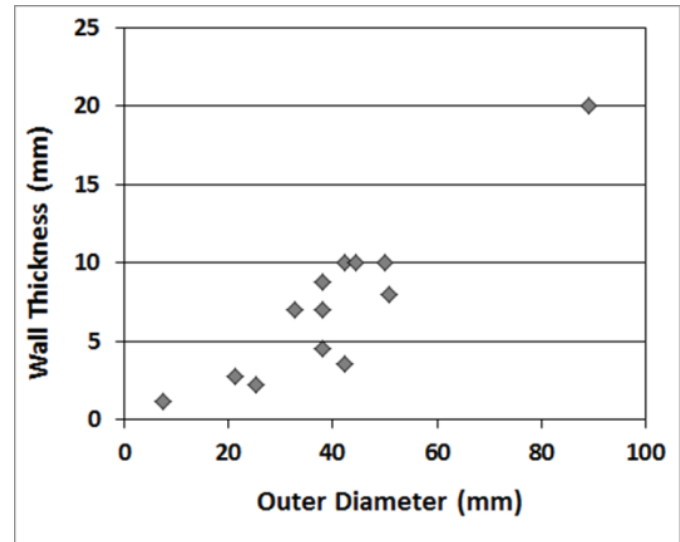

Figure 10. OD/Wall combinations of cold-worked (pilgered or drawn) tube made from $740 / 740 \mathrm{H}$.

The US AUSC project required alloy $740 \mathrm{H}$ to be produced as header and re-heater pipe. These pipes can be very large, with OD and wall of steel pipes as large as $1000 \mathrm{~mm}$ and $100 \mathrm{~mm}$ respectively. Pipes of this size would require ingots larger than any ever previously made from a $\gamma^{\prime}$ strengthened alloy. The first trial was made with a $750 \mathrm{~mm}$ diameter vacuum arc remelt (VAR) ingot produced at Special Metals in Huntington West Virginia. VAR was selected as the remelt process to minimize the chance for macro-segregation. Careful thermal management at each process step was required to prevent thermal stress cracking because $\gamma^{\prime}$ auto aging cannot be prevented in this alloy. Visual examination and chemistry traverses of the head and toe macroetch slices showed no segregation [29]. Figure 11 shows a photograph of the first ingot in the shop after VAR. Ingots of 825 mm diameter weighing $11,800 \mathrm{~kg}$ have since been made.

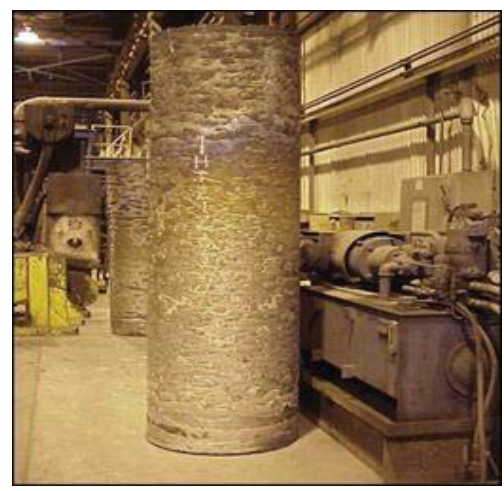

Figure $11.750 \mathrm{~mm}$ diameter, $7570 \mathrm{~kg} 740 \mathrm{H}$ ingot in VAR shop at SMC Huntington.

The homogenized, cropped and conditioned ingot was converted to pipe at the Wyman-Gordon plant in Houston Texas. The process consisted of two major steps. First the ingot was blocked and pierced in a vertical $14 \mathrm{KT}$ closed die potting press. The billet was then machined and radiused and extruded to pipe on a $35 \mathrm{KT}$ vertical press. The final pipe dimensions were $378 \mathrm{~mm}$ OD x 88 $\mathrm{mm} \mathrm{W} \times 10.5 \mathrm{~m} \mathrm{~L}$. The pipe is shown in Figure 12. Apart from a few minor OD tears at the nose, the surface quality was excellent [30]. At the time, this was the largest superalloy pipe ever produced. Even larger pipes will be needed for the reheater section of the A-USC boiler. Alloy $740 \mathrm{H}$ has a significant advantage of having $25-33 \%$ lower flow stress than alloys such as 617 that have much higher Mo content. This is significant because the maximum pipe size will be press force limited. Klingensmith projected that a pipe as large as $750 \mathrm{~mm}$ ID with $75 \mathrm{~mm}$ W could be extruded on the Wyman-Gordon press [30]. Subsequently, ten additional $740 \mathrm{H}$ pipes were extruded and installed in a power plant in Asia.

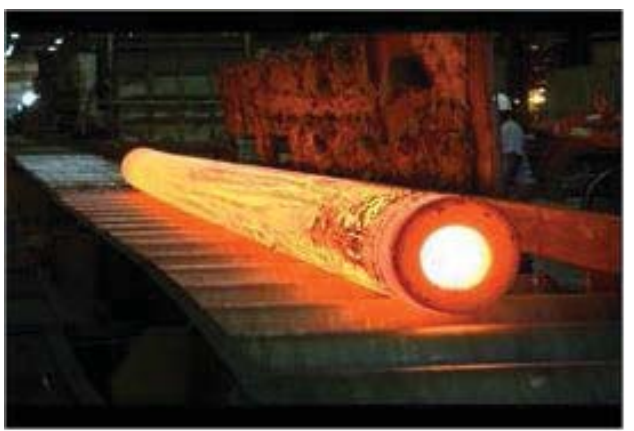

Figure 12. First $740 \mathrm{H}$ Extruded pipe on cooling table at WymanGordon

Thin-wall pipes of any alloy are difficult to extrude and this is especially true of $\gamma^{\prime}$ strengthened alloys. One way to overcome this limitation is by cold roll forming. This is an incremental rotary forming process used for the manufacture of thin-wall seamless rocket and missile cases. Material for roll forming can come from trepanned billet or extruded pipe. Multiple rolling and annealing operations can be used to make pipe configurations not possible by extrusion alone. For thin-wall pipes with OD greater than $300 \mathrm{~mm}$, roll forming may be the only option. This process has been applied at PCC Rollmet in Irvine California to make short sections of pipe for an innovative power plant using supercritical $\mathrm{CO}_{2}$ as the working fluid. The range of pipe sizes made by extrusion and roll forming is shown in Figure 13.

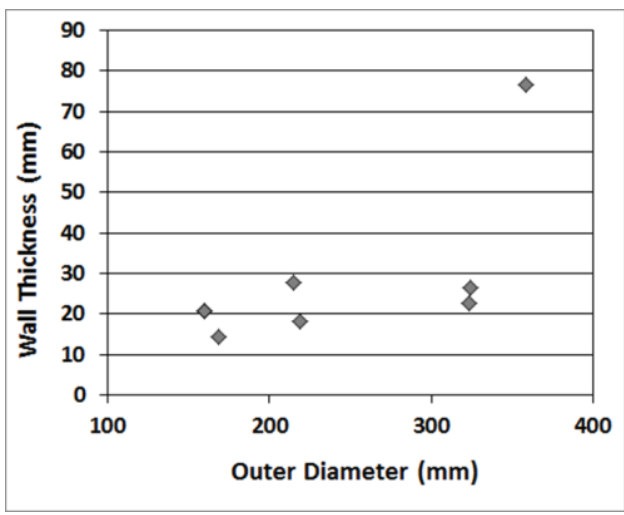

Figure 13. Extruded pipe and trepanned and cold roll formed pipe dimensions.

In addition to straight lengths of tube and pipe, power plant construction requires elbows, return bends, flared or swaged ends, and a wide range of fittings such as flanges, saddles, tees and wyes. Manufacture of these parts involves complex forming operations where temperature, strain and strain-rate control may be difficult, potentially resulting in cracking or undesirable microstructures. 
The US consortium extensively investigated tube bending in its' early development work. It was found that alloy $740 \mathrm{H}$ tubes could be readily bent hot or cold when the material was in the solution annealed condition. Bending in the age-hardened condition is difficult and is not recommended due limited ductility and the possibility of strain-age cracking. Shingledecker [31] and Kubishiro [32] independently studied the synergistic effect of cold bending strain and heat-treatment on creep rupture properties. They found that cold strain on the order of $10 \%$ significantly reduced creep strength. This was accompanied by extensive void formation in the extrados of the bent tube as shown in an internally pressurized creep test [31]. Based on these studies, the ASME Code Case 2702 mandates that the bend must be solution annealed if cold deformation exceeds $5 \%$,

Large pipes must be bent hot. One method commonly used for steel pipe is hot induction bending. Bending trials are expensive due to the quantity of material required and hence have only recently been performed on alloy $740 \mathrm{H}$. Figure 14 shows a trial in progress at Chicago Bridge and Iron Company (CB\&I) Alloy Piping Products (APP) in Clearfield, Utah. Pipes of $133 \mathrm{~mm}$ OD x $19 \mathrm{~mm} \mathrm{~W}$ were bent to a $400 \mathrm{~mm}$ radius. While some dye penetrant indications were observed on the extrados on these early trials, they were removed by spot grinding with no violation of wall tolerance.

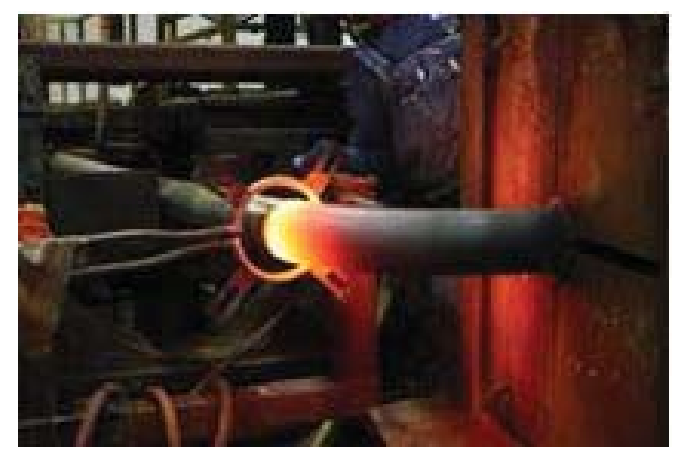

Figure 14. Alloy $740 \mathrm{H}$ pipe induction bending trial at CB\&I APP.

Several small fittings were made from alloy $740 \mathrm{H}$ to specifications for a $\mathrm{sCO}_{2}$ pilot plant now under construction. The forge shops selected were familiar with forming alloy 625 , but had never previously worked with a $\gamma^{\prime}$ strengthened alloy. One concern in forging small parts is that the temperature will drop too low allowing the precipitation of $\gamma^{\prime}$ during the forming operation. The resultant strain-aging can cause cracking. This is of particular concern when the forming operation involves thin section and biaxial stretching. Examples of successfully produced fittings are shown in Figure 15a-15d.

The weld-neck flange was made at Maass Flange Corporation in Houston Texas from hot forged bar. It was upset on a hydraulic press, hammer-forged in two sessions to shape and then the center-punched. The other parts were made from pipe at the CBI APP shop in Shreveport Louisiana. The Tee was made by cold hydroforming in three forming and annealing cycles. The elbow was hot upset to thicken the wall and then open-die ovalized and forged.
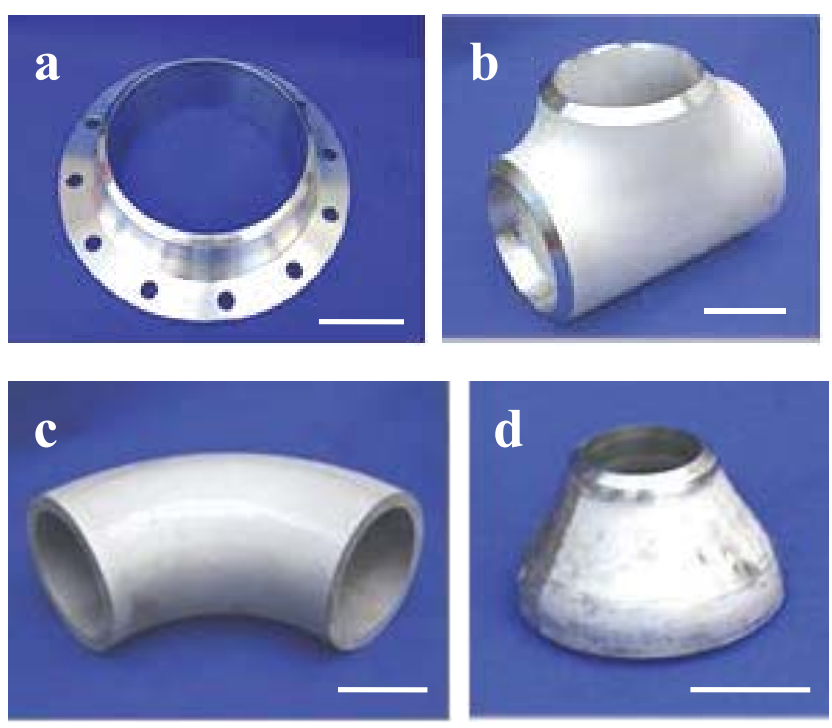

Figure 15. a) $300 \mathrm{~mm} 68 \mathrm{~kg}$ hammer forged weld-neck flange, b) $200 \mathrm{~mm}$ sch. 120 cold hydro-formed Tee, c) $200 \mathrm{~mm} \mathrm{sch} .120$ hot forged elbow, d) $200 \mathrm{~mm}$ sch. 120 to $100 \mathrm{~mm}$ sch. 120 cold forged concentric reducer. Size-bar is $\sim 100 \mathrm{~mm}$.

The concentric reducer was cold forged in three forge-anneal cycles. Each part was solution treated and aged per ASME requirements and tested. A detailed assessment of the structure and properties will be presented elsewhere [33]. These trials show that many common fittings can be successfully fabricated from alloy $740 \mathrm{H}$. However, close collaboration on process development will be needed as more forgers become involved. One part that may be needed for an AUSC plant is a Wye forging (nominally $350 \mathrm{~mm}$ outlet diameter with $75 \mathrm{~mm}$ wall) may be especially difficult.

\section{Do Fabricated Components Reproduce the Qualification Properties?}

The data base for the ASME Code Case was generated from coldworked tube and hot-rolled plate for a limited number of compositions of both 740 and $740 \mathrm{H}$. This selection of material and heat treatment produced a uniform ASTM 3-5 grain size and $\gamma^{\prime}$ structure and consistent properties. But it is not uncommon for commercially produced material and especially complex forgings to have properties different from pilot scale or first article products used for material qualification. There are many reasons for this and the concern is well recognized; hence the need to demonstrate a new alloy's capability under typical manufacturing conditions.

Since boiler tube is solution annealed after cold working and nickel alloys do not develop a strong crystallographic texture, the properties are not expected to be strongly affected by cold working method (pilger, draw or roll form) but annealing practices can have an influence on properties and microstructure. Commercially, both batch and continuous annealing methods are used. In the case of heavy-pipe, the batch solution anneal step is done immediately following extrusion and conditioning. The grain size of pipes is in the ASTM 0-3 range as a consequence of the high extrusion temperature. In very heavy-wall pipes, heavy forgings and machining quality bar it is impossible to suppress $\gamma^{\prime}$ formation on cooling from solution anneal. This auto-aging effect 
produces a duplex precipitate structure containing some coarse $\gamma^{\prime}$. In complex forged parts and bends where strain, strain rate and temperature vary throughout the cross-section, a gradient of microstructure and properties is to be expected.

It is too soon to quantify the range of property variability with the limited number of production tests and non-optimized processes. Selected tensile and impact data are shown in Table 2. To date, all of the tube, pipe and fabricated parts have met the minimum ASME/ASTM tensile requirements but in many cases trend to the low side of the code data package strength and to the high side on ductility suggesting an under-aged condition.

Table 2. Room temperature mechanical property data for solution annealed and aged alloy $740 \mathrm{H}$ in various sizes and product forms.

\begin{tabular}{|c|c|c|c|c|c|c|}
\hline Form & $\begin{array}{c}\text { OD } \\
(\mathrm{mm})\end{array}$ & $\begin{array}{c}\text { YS, } 0.2 \% \\
\text { (MPa) }\end{array}$ & $\begin{array}{c}\text { UTS } \\
\text { (MPa) }\end{array}$ & El (\%) & RA (\%) & $\begin{array}{c}\text { CVN } \\
\left(\mathrm{J} / \mathrm{cm}^{2}\right)\end{array}$ \\
\hline ASME Min. & & 620 & 1035 & 20 & & \\
\hline \multirow[t]{7}{*}{ Tube } & 21.3 & 746 & 1163 & 42.8 & & \\
\hline & 38 & 729 & 1110 & 36 & & \\
\hline & 38 & 761 & 1164 & 37 & & 114 \\
\hline & 38.1 & 769 & 1118 & 33.9 & & \\
\hline & 42.2 & 731 & 1158 & 36.3 & & 117 \\
\hline & 50 & 747 & 1172 & 37.5 & & \\
\hline & 50.8 & 767 & 1174 & 35.9 & & 100 \\
\hline \multirow[t]{3}{*}{ Pipe } & 219.1 & 756 & 1158 & 37.6 & 33.2 & 92 \\
\hline & 323.8 & 741 & 1083 & 33.6 & 36.2 & \\
\hline & 358.2 & 728 & 1094 & 31.8 & 32.4 & 51 \\
\hline \multirow[t]{3}{*}{ Bar } & 76.2 & 736 & 1147 & 36.5 & & \\
\hline & 270 & 730 & 1063 & 23.9 & 24.4 & \\
\hline & 345 & 681 & 1070 & 30.2 & 25.8 & 76.3 \\
\hline \multirow[t]{2}{*}{ Flange } & Web & 682 & 1048 & 44.3 & 34.2 & 178 \\
\hline & Base & 707 & 1064 & 46.4 & 41.8 & 229 \\
\hline Elbow & 200 & 685 & 1060 & 41.2 & 40 & \\
\hline Reducer & $200 \times 100$ & 720 & 1150 & 40.5 & 49.7 & \\
\hline
\end{tabular}

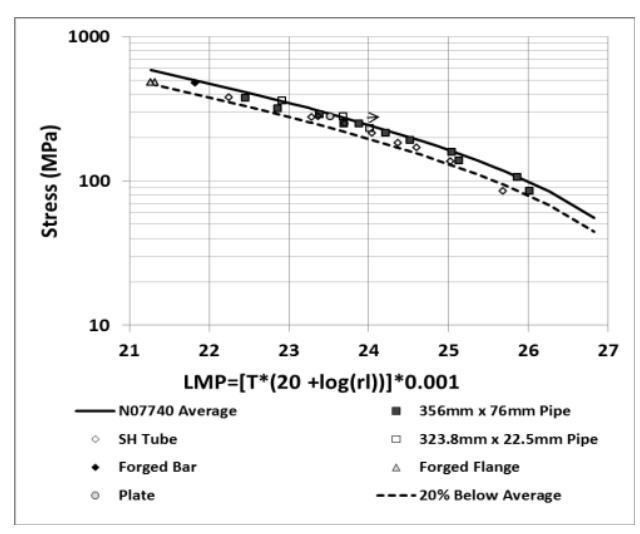

Figure 16. Creep-rupture test data for various $740 \mathrm{H}$ product forms and sizes. Solid line is polynomial fit of data submitted for the ASME code case. The dotted line is minus $20 \%$ of the polynomial.

Creep-rupture data plotted in parametric form in Figure 16 compare with the median of the code data. Again all of the data fall short of the ideal curve but within the $20 \%$ scatter band common to the boiler industry creep data. These test data include various orientations, test samples and test locations.
5. Can the Alloy be Welded in Heavy Section in the Shop and in the Field?

One essential attribute for an alloy candidate for boiler tube and pipe is weldability. Much of the weld procedure development on alloy $740 / 740 \mathrm{H}$ was done in a close collaboration between Special Metals and Babcock \& Wilcox, Barberton Ohio with significant financial support from the US AUSC Consortium. The initial work was done on alloy 740 boiler tube produced at Special Metals Hereford. This work established gas-tungsten arc (GTAW) and gas-metal arc (GMAW) as suitable welding processes and showed that the alloy had good operability, tensile and bend properties. Cross-weld creep rupture testing of girth welds performed at Oak Ridge National Lab was used to define the weld creep-strength reduction factor of 0.70 . This factor must be applied for seam welds but may not apply for girth welds. However, multi-pass welds in $75 \mathrm{~mm}$ thick plate exhibited extensive liquation fissuring in both weld metal and heat affected zone [13]. The subsequent composition changes to remediate this problem focused on reducing the solidus-liquidus temperature range by decreasing $\mathrm{Si}, \mathrm{Nb}$ and $\mathrm{B}$ contents. The modified $740 \mathrm{H}$ alloy retained the desirable weldability attributes of 740 with minimal susceptibility to liquation cracking [34, 35].

One of the iconic welded structures in a conventional coal-fired power plant steam boiler is the header pipe where boiler tubes are attached to nipples inserted into a large cross-section pipe that transfers the supercritical steam to the re-heater and turbine. In an AUSC plant the header will be many meters length and incorporate individual pipes butt welded together with hundreds of tube insertions. Boiler headers will be fabricated in multiple segments at the factory, but final erection will be at the plant site. To gain an early demonstration of capability, Special Metals produced the model header shown in Figure 17 a-b using a welding fixture at Babcock \& Wilcox [36]. The pipe sections were cut from the $378 \mathrm{~mm}$ OD x $88 \mathrm{~mm}$ W pipe shown in Figure 12. The welds were made using a hot-wire narrow-groove GTAW process with fixed torch and rotating work piece. Argon- $25 \% \mathrm{He}$ was used as the shielding gas. Matching composition alloy $740 \mathrm{H}$ filler wire was used. Successive welds with 5, 2 and 1 degree bevels were made. The girth welds were aged per ASME code requirement at $800{ }^{\circ} \mathrm{C}$ using a ceramic tile heating blanket. This method is commonly used in the field for post-weld heattreatments (PWHT). The short nipples were cut from tube and inserted into predrilled holes in the pipe. They were GTAW welded internally using a unique rotary torch. The external welds were made by manual GTAW. No cracks, pores or fissures were detected by radiographic or ultrasonic testing.
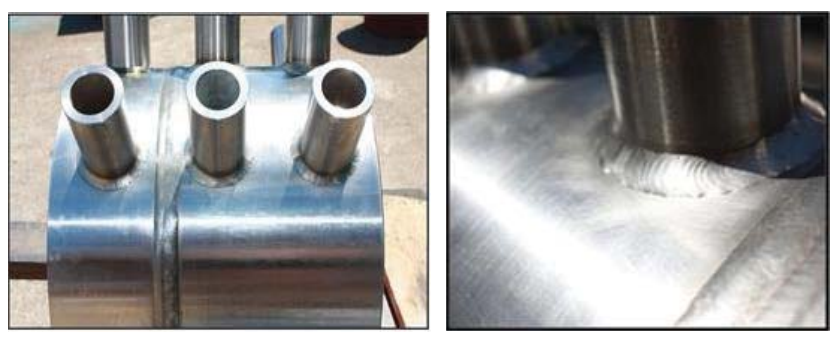

Figure 17. a) Prototype header assembly, b) detail of nipple weld

Welding of thick section pipes has been conducted at Special Metals and by fabricators in Europe, Japan, Korea and China. 
Results have generally been satisfactory in the laboratory but mixed in the plant where production welders lack familiarity with nickel alloys. Special Metals collaborated with Babcock \& Wilcox to prepare a practical welding guide [37] which has been used to instruct operators in the US and China.

\section{Will the Alloy Welds Survive Power Plant Thermal Cycles?}

In service, weld cracking is a major concern for power plants because of the cost of down time and repair and difficulty in detecting incipient cracks. The newer high-strength 9-12 chromium ferritic steels are especially sensitive to coarse-grain heat-affected zone (HAZ) cracking that may not become evident until thousands of hours of service. Failure to follow welding and stress relief procedures are frequently the root cause of this cracking. Concern was raised about all nickel-base alloys when an alloy 617 header that did not receive PWHT, developed a crack after 20,000 $\mathrm{h}$ exposure in the COMTES700 test loop [38]. This concern is heightened by the poor stress-relief cracking resistance of some $\gamma^{\prime}$ strengthened alloys such as Waspaloy.

It is difficult to assess an alloy's resistance to stress-relief and stress-relaxation cracking, and there is no generally accepted test for life prediction of a complex joint. Stress-relief cracking is normally evident immediately after PWHT, but stress relaxation cracking may occur after years of operation. In early work, Ramirez [39] used a Gleeble test with a thermal and stress cycle programmed to simulate a weld and stress-relief cycle. He concluded that alloy 740 had similar stress-relief cracking resistance to alloy 718 , but that does not provide much assurance for performance in a power plant. Further anecdotal evidence of alloy $740 \mathrm{H}$ resistance to cracking is provided by the dozens of successful restrained weld tests performed in the laboratory. No incidence of cracking was encountered in these tests. This may be in part due to the relatively low weld metal strength of $740 \mathrm{H}$ combined with the virtual absence of a coarse-grain HAZ that distributes the creep strain over a much wider area.

The Borland test is a more elaborate and time consuming test that was developed at The Welding Institute (TWI) and is widely used in the UK [40]. This test more accurately reproduces weld joint conditions, but it is not quantitative. In tests run at Special Metals, $37 \mathrm{~mm}$ thick plates with a machined circular U-groove were tack welded to a strong-back. The groove was filled in ten passes using a manual GTAW process. The plate was given an $800{ }^{\circ} \mathrm{C}$ PWHT and then exposed at $700{ }^{\circ} \mathrm{C}$ for $10,000 \mathrm{~h}$. The plates were checked every $1000 \mathrm{~h}$ by radiographic and ultrasonic testing to detect the development of cracks. After completion of the test, the plates were sectioned for metallographic examination. Several "lack of fusion" and liquation cracks were found, but there was no evidence that the cracks extended during the high temperature exposure in the presence of a residual stress. There was no sign of creep voids in the weld or at the fusion line. This is a very encouraging result, but it is being repeated using more severe conditions. Additional work is now underway in projects at the National Science Foundation Industry/University Cooperative Research Center (NSF I/UCRC) at Lehigh and Ohio State Universities guided by EPRI, Babcock \& Wilcox, Special Metals and others.
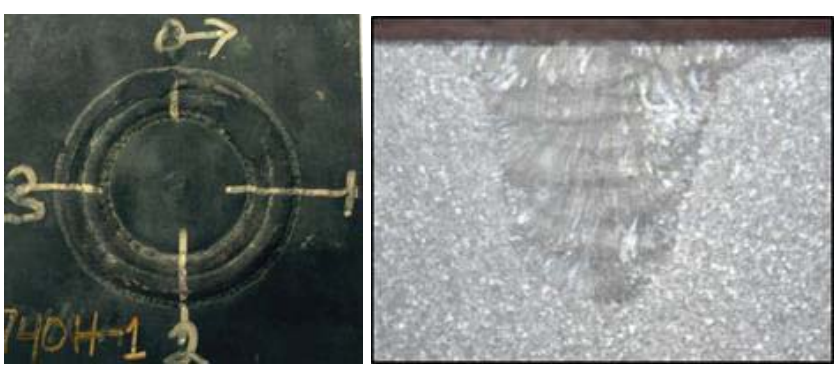

Figure 18. a) Appearance of Borland test plate after 10,000 h exposure at $700{ }^{\circ} \mathrm{C}$, b) Cross-section of weld bead (cap machined off for NDT prior to mounting)

\section{Is the Alloy Damage Tolerant and if Damaged can it be Inspected and Repaired?}

Damage tolerance is of increasing concern to the electric utility industry because high performance materials tend to be less ductile and hence less forgiving to microstructural "damage" such as creep voids, weld defects, fatigue cracks and localized corrosion. The current focus of research is on the so-called creepstrength enhanced ferritic (CSEF) steels such as P91, P92 and P122 that are used in the modern fleet of USC steam boilers. Age hardened superalloys that are much stronger and largely unknown to the industry will begin to get attention once AUSC plants come on stream.

Nickel alloys differ from ferritic steels in a number of ways that pose possible issues for damage tolerance. For example ferritic steels often display the classic three stage creep curve whereas age-hardened austenitic alloys may show no discernible steady state segment of the creep curve. Some design formulas are based on the assumption that void formation begins at the start of tertiary creep which may comprise less than a quarter of the total rupture life. In the case of austenitic alloys the beginning of stage three creep may begin within the first quarter of the total rupture life. That probably does not correspond to void formation, but there is currently no external indication of when void formation does occur. Furthermore rupture ductility of age-hardened alloys may be quite low, further reducing the margin of safety. In the case of $740 \mathrm{H}$, creep elongation values under $5 \%$ have been observed in tests at $650^{\circ} \mathrm{C}$. This is strictly a rupture mechanism effect as topological close packed (TCP) phases have not been observed. A typical microstructure near the fracture surface of a creep-rupture bar is shown in Figure 19a. Note the chain of voids that decorate the grain boundaries. The effect of this kind of structure on impact toughness or fatigue properties has not been assessed.

Precipitate-free zones (PFZ) are commonly seen in age-hardened alloys, but in the case of $740 \mathrm{H}$ welds they appear to form by a unique mechanism. Bechetti has investigated this effect in an effort to understand why $740 \mathrm{H}$ weld metal has lower creep strength than the base metal [41]. The root cause is partitioning of strengthening elements during weld solidification. But the PFZ phenomenon is actually caused by discontinuous precipitate growth coupled with grain boundary migration. The coarse "sharks tooth" particles visible in Figure 19b are actually $\gamma^{\prime}$ growing perpendicular to the grain boundary. It is unclear whether this unique structure is actually related to the loss of creep strength, but it may be a potential fatigue crack initiation site. 

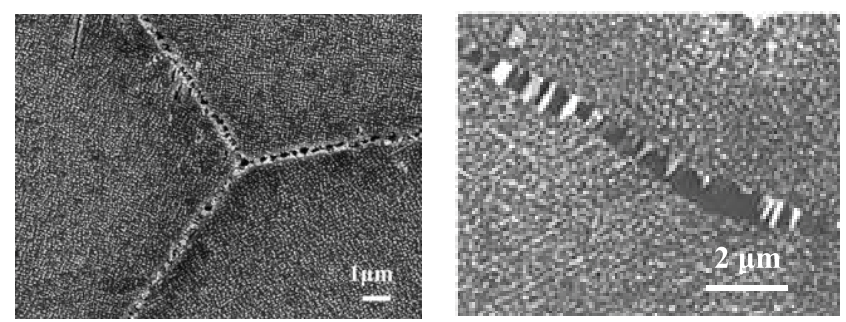

Figure 19. a) Creep voids at triple point near the fracture surface of $740 \mathrm{H}\left(750^{\circ} \mathrm{C}, 280 \mathrm{MPa}, 1087.4 \mathrm{~h}\right)$ [27], b) Coarse $\gamma^{\prime}$ and PFZ in weld metal $\left(750^{\circ} \mathrm{C}, 200 \mathrm{MPa}, 270 \mathrm{~h}\right)$ [41].

Currently there is no universal way to assess damage tolerance; however, this will be a prime area of investigation when the demonstration plants now being designed have operated for several years. A better understanding of this phenomenon is essential for the full-scale commercialization of AUSC that may begin after 2020 .

\section{Conclusions}

The development of superalloys for AUSC applications is now in its $18^{\text {th }}$ year. Several in-plant test loop projects have been completed and the design and construction of pilot plants for AUSC and $\mathrm{sCO}_{2}$ is well underway. Given the conservative nature of the Electric Utility industry, the development and especially the qualification of nickel-base superalloys for use in pressure piping would have been impossible without the collaboration of materials suppliers, forgers, fabricators, systems designers and utilities along with infusion of public funding and use of technical assets of federal labs and universities. It should also be recognized that while each of the national AUSC consortia have charted their own course in terms of materials selection and characterization, the cross fertilization between these consortia has been tremendously valuable. In particular the triennial Conferences on Advances in Materials Technology for Fossil Power Plants, hosted by EPRI, has served as the key international forum to bring materials experts together to share ideas and results. The most recent proceedings volume was almost four inches thick! An unexpected additional benefit has been the introduction of superalloys into the emerging sCO2 technology. This energy transfer medium is likely to be enabling for the next generation of more efficient fossil, nuclear and solar electricity generating systems. The world of new energy technology is tremendously exciting and nickel-base superalloys will play a key role in it.

\section{References}

1. C.T. Sims, N.S. Stoloff, and W.C. Hagel, Superalloys II, (New York, NY: John Wiley \& Sons, 1987).

2. C.T. Sims, "A History of Superalloy Metallurgy for Superalloy Metallurgists," Superalloys 1984, ed. Gell et al, (Warrendale, PA: TMS, 1984), 401-422.

3. W. Betteridge and J. Heslop, The Nimonic Alloys, $2^{\text {nd }}$ edition, (New York, NY: Crane, Russak Company, Inc., 1959).

4. W. Betteridge and S. Shaw, "Development of Superalloys", Materials Science and Technology, 3, (1987), 682-694.
5. P. Schilke, J.J. Pepe and R.C. Schwant, "Alloy 706 Metallurgy and Turbine Wheel Applications," Superalloys 718, 625, 706 and Various Derivitives, ed. E.A. Loria, (Warrendale, PA: TMS 1994), 1-11.

6. J. Chater, "Going Ultrasupercritical: How energy demand and environmental imperitive are driving development in the power generation industry," Stainless Steel World, July/August, (2010), $39-43$.

7. J. Wheeldon, (Presented at Workshop on the US Dept. of Energy/Ohio Coal Development Office Advanced Materials for Ultrasupercritical Power Plants Projects, Washington, DC, April 7, 2011).

8. K. Nichol, Status of Advanced Ultra-supercritical Coal-fired Power Plant, (London, UK: IEA Clean Coal Centre, 2013).

9. G.D. Smith and H.W. Sizek, H.W., "Introduction of an Advanced Superheater Alloy for Coal Fired Boilers," NACE Corrosion 2000, (Houston, TX: NACE Paper No. 00256).

10. V. Viswanathan et al., "Coal-Fired Power Materials," Advanced Materials \& Processes, Part 1, August 2008, 47-49, Part II, September 2008, 41-45.

11. J. Shingledecker et al., "Current Status of the U.S. DOE / OCDO A-USC Materials Technology Research and Development Program," 7th Int. Conf., Advances in Materials Technology for Fossil Power Plants, ed. EPRI, (Materials Park OH: ASM Int. 2013), 43-52.

12. X. Xie et al, "An Investigation of Structural Stability and Its Improvement on New Developed Ni-Cr-Co-Mo-Nb-Ti-Al Superalloy”, Material Science Forum, 475, 613, (2005).

13. J.M. Sanders, J.E. Ramirez and B.A. Baker, B.A., "Weldability Investigation of INCONEL Alloy 740 for Ultra Supercritical Boiler Applications," 5th Int. Conf.: Advances in Materials Technology for Fossil Power Plants, ed. EPRI, (Materials Park, OH: ASM Int., 2008), 818-829.

14. B.A. Baker and R.D. Gollihue, "Optimization of INCONEL alloy 740 for Advanced-Ultrasupercritical Steam Boilers," 6th Int. Conf.: Advances in Materials Technology for Fossil Power Plants, ed. EPRI, (Materials Park, OH: ASM Int., 2010), 96-109.

15. "Case 2702 Seamless Ni-25Cr- 20Co Material, Section 1", Cases of the ASME Boiler and Pressure Vessel Code, BPV-Supp. 7 2011, (New York, NY: ASME, 2011).

16. J.P. Shingledecker, "Creep-Rupture Performance of INCONEL Alloy 740 and Welds," 7th Int. Conf.: Advancements in Materials Technology for Fossil Power Plants, ed. EPRI, (Materials Park, OH: ASM Int. 2013), 230-241.

17. P.F. Tortorelli et al., "Creep-rupture Behavior of PrecipitationStrengthened Ni-Based Alloys Under Advanced Ultrasupercritical Steam Conditions," 7th Int. Conf.: Advances in Materials Technology for Fossil Power Plants, ed. EPRI, (Materials Park, OH: ASM Int., 2013), 131-142. 
18. S. Zhang and Y. Takahashi, "Evaluation of High Temperature Strength of a Ni-Base Alloy $740 \mathrm{H}$ for Advanced UltraSupercritical Power Plant," 7th Int. Conf.: Advances in Materials Technology for Fossil Power Plants, ed. EPRI, (Materials Park, OH: ASM Int., 2013), 242-253.

19. J.M. Sarver and J.M. Tanzosh, "Steamside Oxidation of Candidate USC Materials at $650^{\circ} \mathrm{C}$ and $800^{\circ} \mathrm{C}$," 4 th Int. Conf. Advances in Materials Technology for Fossil Power Plants, ed. EPRI, (Materials Park, OH: ASM Int., 2004), 402.

20. Maitra, D., Baker, B.A. and Smith, "Oxidation Behavior of Candidate Alloys for Advanced-Ultra Super Critical Boiler Application", NACE Corrosion 2013, (Houston, TX, NACE Int., Paper No. 2280, 2013).

21. M. Tamura et al. "Promising Alloys for the Heat Exchangers of Advanced Coal Fired Boilers", Exposition and Symposium on Industrial Heat Exchanger Technology, (Materials Park, OH: ASM Int., 1985), 273.

22. B.A. Baker et al. "Manufacturing Demonstration of INCONEL Alloy $740 \mathrm{H}$ for AUSC Boilers," 7th Int. Conf.: Advances in Materials Technology for Fossil Power Plants, ed. EPRI, (Materials Park, OH: ASM Int., 2013), 215-219.

23. G.D. Smith et al. "Assessment of the Coal Ash Corrosion Resistance of Nickel-Base Alloys in Advanced Ultra-supercritical Boiler Environments," $37^{\text {th }}$ International Technical Conference on Clean Coal and Fuel Systems, Sarasota, FL, 2012, CD.

24. S.C. Kung, "High-Temperature Corrosion Mechanisms for Selected Iron and Nickel-Based Alloys Exposed to Sulfur and Chlorine-Containing Environments," Corrosion, 71, (4), (2015), 483-501.

25 . R. Ganta et al. "Steam Loop Testing of A-USC Materials for Oxidation and Fireside Corrosion - Alstom's Experience to Date", $7^{\text {th }}$ Int. Conf: Advances in Materials Technology for Fossil Power Plants, ed. EPRI, (Materials Park, OH: ASM Int., 2013), 832-862.

26. J.P. Shingledecker and G.M. Pharr, "The Role of Eta Phase Formation on the Creep Strength and Ductility of INCONEL Alloy 740 at $1023 \mathrm{~K}\left(750^{\circ} \mathrm{C}\right)$," Met. Trans. A, 43, (2012), 19021910.

27. C. Chi et al. "Structure Stability Study on INCONEL $740 / 740 \mathrm{H}$ Ni-Base Superalloy for $700^{\circ} \mathrm{C}$ AUSC Power Plant Application," The $5^{\text {th }}$ Symposiun on Heat Resistant Steels and Alloys for High Efficiency USC/AUSC Power Plants, ed KIST, Seoul, Korea, 2013).

28. J.J. deBarbadillo, B.A. Baker, and X. Xie, "Microstructure Stability of Alloy $740 \mathrm{H}$ and its Effect on Material Properties", Symposium on Elevated Temperature Application of Materials for Fossil, Nuclear and Petrochemical Industries, (New York, NY: ASME, 2014).

29. J.J. deBarbadillo et al., "Nickel-Base Superalloys for Advanced Ultra-Supercritical Power Plants," Global Advanced Fossil-Gen Summit 2011, (Shanghai, CH: Asian Coalition for Climate and Energy, 2011), 244-272.
30. L. Klingensmith, "Development of Extruded Heavy Wall Large Diameter Nickel Base Alloy Piping for A-USC Power Plants," Global Advanced Fossil-Gen Summit 2011, (Shanghai, CH: Asian Coalition for Climate and Energy, 2011), 272-298.

31. J.P. Shingledecker, J.P. and G.M. Pharr, G.M., "Testing and Analysis of Full-Scale Creep-Rupture Experiments on INCONEL Alloy 740 Cold-Formed Tubing" Journal of Materials Engineering and Performance, 22 (2) (2013), 454-462.

32. K. Kubishiro et al., "Effect of Pre-Strain on Creep Properties of Alloy 740", 6th Int. Conf.: Advances in Materials Technology for Fossil Power Plants, ed. EPRI, (Materials Park, OH: ASM Int., 2010), 164-170.

33. J.J. deBarbadillo and B.A. Baker, "INCONEL alloy 740H Development of Fittings Capability for AUSC Applications," $8^{\text {th }}$ Int. Conf.: Advances in Materials Technology for Fossil Power Plants, ed. EPRI, (Materials Park, OH: ASM Int.2016), to be published.

34. J.M. Sanders et al., "Elimination of Fissures in Thick Section Inconel Alloy 740 Welds", $34^{\text {th }}$ Annual International Technical Conference on Clean Coal and Fuel Systems, Coal Technology Association, Clearwater, FL, May 31, 2009.

35. J.A. Siefert et al., "Weldability of Inconel Alloy 740," $6^{\text {th }}$ Int. Conf.: Advances in Materials Technology for Fossil Power Plants, ed. EPRI, (Materials Park, OH: ASM Int., 2010), 10451066.

36. B.A. Baker et al., "Fabrication and Heat Treatment of Weld Joints in Inconel Alloy 740H Superalloy Steam Header Pipe and Superheater Tubing," Welding and Repair Technology for Power Plants, 10th International EPRI Conference, Marco Island, FL, June 26-29, 2012.

37. R.D. Gollihue et al., "Practical Guide for Welding Inconel Alloy 740H", $7^{\text {th }}$ Int. Conf.: Advances in Materials Technology for Fossil Power Plants, ed. EPRI, (Materials Park, OH: ASM, Int., 2013), 1025-1038.

38. G. Schmidt, et al, "Component Test Facility for a $700^{\circ} \mathrm{C}$ Power Plant (COMTES 700)", Final Report to the European Commission, Directorate General for Research and Innovation, EUR 2591, Luxembourg, 2013.

39. J.E. Ramirez, "Evaluation of Susceptibility of Alloy IN740 to HAZ Stress Relaxation Cracking," Welding Journal, 92, (2013), 89s-100s.

40. J.C. Borland, "Cracking Tests for Assessing Weldability," British Welding Journal, 7, (1960), 508-512.

41. D.H. Bechetti et al., "Microstructural Evolution of INCONEL alloy $740 \mathrm{H}$ Fusion Welds During Creep", Met. Trans. A, TMS, 46A, (2016), 739-755. 